\title{
Psychopathic disorder: a category mistake? A legal response to Colin Holmes
}

\author{
Irene Mackay University of Manchester
}

\section{Author's abstract}

Holmes is concerned with a conflict between law and medicine about the problem of psychopathy, in particular as it relates to homicide.

He looks for a consistent set of legal principles based on a variety of medical concepts and in doing so criticises the court for its commonsense approach, its disregard for medical evidence and for employing lay notions of responsibility and illness.

This commentary explores how Holmes's notions fit into existing legal rules and explains how the court seeks the assistance of medical evidence when looking at the evidence as a whole to enable it to decide upon issues of defence, which involve legal and not medical concepts.

There is a difficulty inherent in this paper, as it seeks to explain the law relating to insanity and diminished responsibility (1). Holmes covers a wealth of material but presents a confusing and inaccurate picture of how the law actually works today.

Holmes's material includes references to several common law jurisdictions. Although they all have common origins, the statutory rules vary widely. I can comment only on the English rules.

Holmes attempts to show some relationship between the Homicide Act 1957, the Mental Deficiency Acts 1913 and 1927 and the Mental Health Act 1959. He makes no reference to the Mental Health Act 1983, which consolidates the law relating to the care and treatment of mentally disordered persons. There is no relationship, in the suggested sense, between the Homicide Act 1957 and the Mental Health Act 1983.

The Mental Deficiency Acts 1913 and 1927 dealt with provision for the care of mentally defective persons. The Mental Health Act 1959 repealed these Acts and made fresh provision for the treatment and care of mentally disordered persons. The Mental Health Act 1983 consolidated the law in this regard.

The purpose of the Homicide Act 1957 is entirely different. It came into force to amend the law relating to homicide and the trial and punishment of murder. In particular, Section 2 creates the specific defence of

\section{Key words}

diminished responsibility upon which I propose to comment.

The absence of any established medical or psychiatric definition of 'moral insanity' or 'psychopathy' is noteworthy in this article by Colin $\vec{c}$ Holmes. It is not clear whether either can be referred to correctly as an illness or whether the two could be ${ }^{\Phi}$ synonymous. Moral insanity is referred to as 'absence $\vec{\emptyset}$ of conscience', 'no capacity for true moral feelings', 'depravity', and 'absence of moral scruple'. Psychopathy appears to mean 'total lack of compunction or consequent moral emotion', 'absence of conscience', 'inability to experience guilt' and 'lack of respect for the moral claims of others'.

Holmes is concerned with the conflict between law $\stackrel{2}{\Rightarrow}$ and medicine about what he refers to as the problem of $\frac{0}{3}$ psychopathy. He criticises the courts and juries for $\frac{3}{2}$ basing their decisions on 'prevailing common-sense notions of morality, responsibility and for disregarding medical evidence as irrelevant or misguided'. Juries, he feels, should not employ lay notions of $\frac{\square}{\sigma}$ responsibility and illness, nor should they reject pleas 3 . of manslaughter where there is evidence of $\delta$ psychopathy or irresistible impulse.

I propose to explore how Holmes's notions actually $ᄋ$ fit into existing legal rules in England.

'Moral insanity' is not a concept known in English Law, 'psychopathy' does not feature in the legal $\bar{N}$. definition of diminished responsibility (2) and $\%$ 'irresistible impulse' is not a recognised defence to a N criminal act. Does the law fall short by not including $\underset{\omega}{N}$ these as defences?

English Law presumes that a man is responsible for his actions unless the contrary is proved (3). What $\frac{D}{\Phi}$ circumstances excuse a defendant from criminal $\stackrel{\infty}{+}$ liability? How can a defendant show that he was not 0 responsible for his actions at the time of doing an act $\bar{O}$ which would otherwise amount to a criminal offence? $\stackrel{\mathbb{D}}{\Omega}$

If we start with the common law maxim 'actus non $\overrightarrow{\mathbb{D}}$ facit reum nisi mens sit rea' (4), we see that what lawyers refer to as 'mens rea' must exist, for example, for the offence of murder to be established by the Crown. What then of the accused who is not in control of his 'mind' - ie - his faculties of reason, memory and $\frac{0}{7}$ understanding (5)? Is he responsible, in law, for his $\stackrel{?}{?}$ actions? 
Two main defences arise to be considered in this context. I propose to define these to show how they work and what their consequences are for the defendant.

\section{Insanity}

This is a defence which negatives the required mens rea for the offence charged. It raises the issue that although the defendant, for example, killed his wife with a carving knife, he did not have a blameworthy mind or did not form the required intent to kill her, by reason of his insanity. The defendant must prove on a balance of probabilities that he was insane, as defined by the M'Naghten Rules at the time of the killing. It must be proved that, at the time of committing the act, the defendant was labouring under such a defect of reason, from disease of the mind, as not to know the nature and quality of the act he was doing or, if he did know it, that he did not know he was doing what was wrong (3).

The 'defect of reason' must be due to 'disease of mind' and not any other failure of the mind such as that which might give rise to the defence of non-insane automatism. Automatism refers to an act done automatically, due to some failure of the mind which is not due to disease, for example, when the mind fails to function due to an external factor which was not selfinduced, leaving the defendant acting involuntarily or unconsciously (6).

Interpretation of the phrase 'disease of mind' has proved difficult, in $R v \operatorname{Kemp}(5)$ the accused was charged with causing grievous bodily harm to his wife by striking her with a hammer. It was common ground that at the time he suffered from arteriosclerosis and did not know what he was doing - he did not know the nature and quality of his act. Three doctors who gave evidence disagreed as to whether the illness could amount to a 'disease of mind'. The question to be decided was whether the defendant suffered a defect of reason due to 'disease of mind'? It was held that hardening of the arteries is a disease, which, on the evidence was shown to be capable of affecting the mind in such a way as to cause a defect temporarily or permanently of its reasoning and understanding and is thus a 'disease of mind'. The defendant was found guilty but insane.

The House of Lords considered the question of 'disease of mind' in $R v$ Sullivan (7) and concluded that if the effect of a disease is to impair the mental faculties of reason, memory and understanding so severely as to have either of the consequences referred to in the latter part of the M'Naghten Rules, it matters not whether the aetiology of the impairment is organic, as in epilepsy, or functional, or whether the impairment itself was permanent, or was transient and intermittent.

Holmes accuses the courts of disregarding medical evidence as irrelevant and misguided, preferring to found their decisions on prevailing commonsense and notions of morality, responsibility and justice. Indeed 'responsibility' is of fundamental importance when considering the question of insanity in law. A man is responsible for his actions unless the contrary is proved. Lord Goddard said in his judgement (8):

'A man may be suffering from a defect of reason, but if he knows that what he is doing is wrong - ie - contrary to law - then he is responsible. The test is responsibility according to law.'

It is not sufficient, in attempting to establish the defence of insanity to show that the defendant could not control his impulses. That falls far short of the criteria required by law for insanity to be left as an issue for the jury.

Since the abolition of the death penalty for murder, the popularity of the defence of insanity has waned. Indeed, insanity is rarely pleaded as a defence, quite simply because, although it excuses the defendant by a special verdict of 'not guilty by reason of insanity', under s2 of the Trial of Lunatics Act 1883 (9), 'the court shall make an order that the accused be admitted to such hospital as may be specified by the Secretary of State' (10). Thus, the insane person, absolved of criminal responsibility for his act, will be detained in a hospital in accordance with the provisions of the Mental Health Act 1983. He will be treated as if a hospital order was made under s37 of the said Act. By virtue of $\mathrm{s} 41$ of the Act a restriction order will be made detaining the accused without limit of time (11). So, the 'insane' person is detained in the same way as the convicted criminal who is suffering from a mental illness, a psychopathic disorder, severe mental impairment or mental impairment.

\section{Diminished responsibility}

This defence, which can be classed as a modification of the defence of insanity, is available, as Colin Holmes states, only when the charge is one of murder. That is what Parliament intended. It is a specific statutory defence created by s 2 of the Homicide Act 1957 and the courts are not free to extend it. And do they need to? Murder is the only crime with a mandatory penalty. Issues of diminished responsibility and irresistible impulse in relation to other crimes can be dealt with adequately at the time of sentencing. It was not created as an elaboration of the notion of 'abnormality of mind', as suggested by the writer. The M'Naghten Rules make no reference to 'abnormality of mind'. In fact Lord Parker explained in $R v$ Byrne (12): 'The expression "abnormality of mind" has to be contrasted with the time-honoured expression in the M'Naghten Rules "defect of reason"".

The function of diminished responsibility is to reduce what would otherwise have been a verdict of guilty to murder to one of guilty to manslaughter (13), thereby reducing the criminal responsibility of the defendant. Holmes complains that despite this reduction in responsibility, all too often the sentence is one of imprisonment.

This must be answered by confirming that the court 
has various options but has to sentence, bearing in mind its duty to protect the public, taking into account whether the defendant's condition is treatable and whether suitable facilities for such treatment are available. If they are, then a hospital order will normally be made with an indefinite restriction order or a probation order with a condition that the defendant must undergo psychiatric treatment. In order to safeguard the public from a recurrence of the defendant's behaviour, the only realistic alternative to these measures is a sentence of life imprisonment.

What is required by law to establish the defence of diminished responsibility? Parliament has provided that the defendant has to show:

(a) that he was suffering from an abnormality of mind and

(b) that such abnormality:

(i) arose from a condition of arrested or retarded development of mind or any inherent causes or was induced by disease or injury and,

(ii) was such as substantially impaired his mental responsibility for his acts in doing or being a party to the killing (14).

The expression 'abnormality of mind' appears to cover all aspects of the mind's activities, including the ability to exercise will-power to control physical acts in accordance with rational judgement. The question is whether the accused has a state of mind so different from that of the ordinary person that the reasonable man would term it abnormal. This is a matter for the jury to decide with t'ie help of medical evidence, but, the evidence as a whole must be considered.

Having established that the defendant suffers from abnormality of mind, the jury's next task is to decide whether the defendant has proved on a balance of probabilities that it substantially impaired his mental responsibility for his acts. This includes consideration of the question of self-control and the defendant's ability to control or resist his impulses (11). If the jury is satisfied that the matters before it amount to substantial impairment of responsibility then the defence is made out. Again, medical evidence will usually help the jury to reach its decision, but the definition of diminished responsibility involves legal concepts which must be approached in a commonsense way.

Medical evidence of psychopathy or irresistible impulse will not necessarily be enough to secure a successful plea of diminished responsibility. The jury would have to be satisfied that it amounted to 'abnormality of mind' arising from the conditions required under the section. Likewise, the morally insane or the psychopath will have a special verdict of not guilty by reason of insanity returned, only if the court finds that either of these categories of person suffered from a 'defect of reason' due to disease of mind, which gave rise to either of the consequences set out in the M'Naghten Rules. These are legal and not medical concepts. As Lord Diplock said (6): 'The nomenclature adopted by the medical profession may change from time to time, but the meaning of the expression "disease of the mind" as the cause of a defect of reason remains unchanged for the purposes of the application of the M'Naghten Rules.'

\section{Conclusions}

Criticism of these Rules and of the wording of section 2 of the Homicide Act 1957 is frequent. Argument exists that use of the words 'mental disorder' would assist with solving the problems which arise under each defence, particularly as 'mental disorder' is defined by the Mental Health Act 1983.

Whatever terminology is used to describe the mental condition of the defendant, the concepts used to decide upon matters of defence to criminal acts remain legal concepts. Holmes admits, finally, that psychiatry has made some kind of category mistake so far as psychopathy is concerned and suggests that this concept ought to be left to moral and legal philosophers. In the light of this, perhaps it is a happy safeguard that the court continues to control such decision-making. It has to be accepted, however, that while it does, continued disagreement with the medical profession is inevitable.

Irene Mackay BA, Barrister is a Lecturer in Law (parttime) at the University of Manchester.

\section{References}

(1) Holmes C. Psychopathic disorder: a category mistake? Fournal of medical ethics 1991 ; 17: 77-85.

(2) s2(1) Homicide Act 1957.

(3) M'Naghten Rules. M'Naghten's case (1843) $10 \mathrm{CR}$ and F 200.

(4) 'The deed does not make a man guilty unless his mind is guilty'.

(5) $R v \operatorname{Kemp}$ [1956] 3 All ER 294.

(6) $R v$ Quick [1973] 57 CR App R 722.

(7) $R v$ Sullivan [1983] 2 All ER 637.

(8) Lord Goddard Cf in $R v$ Windle [1952] 2 All ER 2.

(9) As amended by sl Criminal Procedure (Insanity) Act 1964.

(10) s5 Criminal Procedure (Insanity) Act 1964 as amended by s56 and sched 11 of the Courts Act 1971 .

(11) Schedule I of the Criminal Procedure (Insanity) Act 1964.

(12) $R$ v Byrne [1960] 3 All ER 1.

(13) s2(3) Homicide Act 1957.

(14) s2(1) Homicide Act 1957 